\title{
Comedy and humour: an ethical perspective
}

\author{
Mehrdad Bidgoli \\ University of Isfahan, Iran \\ mehrdadbidgoli94@gmail.com
}

\begin{abstract}
In this essay, I aim to study comedy and humour from an ethical perspective. My main proposal is that comedy and humour can be understood alternatively in the light of ethics, and in one sense, they actually begin, more effectively, with an ethical sensibility. Effective comedy and humour initiate through an ethical sensibility called "hospitality"; ideally, they are preceded by this ethical openness. I will argue that it is this pre-original ethical hospitality and openness that can give rise to more effective moments of comedy, humour, carnival, festivity and also laughter, opening the Self to the Other in order to be able to enter into a disinterested humorous (dialogic) experience. Hospitality is of prime importance here because it turns out to be part and parcel of comedy as it also underlies the ethics of alterity. I therefore suggest that the thoughts of both Emmanuel Levinas and Mikhail Bakhtin can give rise to a fruitful study of ethics, comedy and humour. I will "reduce" socio-political complexities of our daily life-world to comic moments through Bakhtin, and then expose the reader to a Levinasian simplicity and ethical openness that actually takes place before effective comedy and humour can begin. In this essay, I mainly have literary/critical aims, and to fulfil that aim, I will briefly discuss two Shakespearean works and contextualize my thesis. The matter of studying comedy, humour and ethics in a broader cultural, social and/or philosophical context is open for other thinkers.
\end{abstract}

Keywords: alterity, carnival, comedy, ethics, Emmanuel Levinas, hospitality, humour, Mikhail Bakhtin, openness.

\section{Introduction}

The most basic and loose definitions of comedy usually characterise it as "a dramatic performance intended to amuse or raise laughter in an audience" (Shaw 2014: 5). This is, however, among the most general elaborations of the term and its genre, and what we see in the comedies of, say, a classic playwright such as Aristophanes offers much more than that. As Clarke (1965: 20) suggests, Aristophanes introduces in his comedies not "general ideas, such as Man's relations with God," but more significantly "local events and conditions" (my emphasis). The comic attacks depicted by Aristophanes, continues Clarke (1965: 20), are often "surprisingly fierce and bitter, and it seems that the governments in Ancient Greece showed remarkable tolerance towards their playwrights." Along the same line, Aristotle in his Poetics 
(1996: 9) suggests that "Comedy is... an imitation of inferior people" and, as Heath reminds us, "“inferior' has both moral and social implications" (1996: 1xii). The philosopher Henri Bergson also argues that comedy and laughter "must have a social signification" (quoted in Critchley 2002: 4). According to Caty Chattoo's (2018: 1) recent discussion, comedy "is a powerful source of public influence and cultural information." "Comedy in serious social issues," as propounds Chattoo, "helps to reduce taboos and open conversation" (2018: 17; my emphasis). The common point these meditations share is that from the ancient times up to our own era, comedy has somehow rested on social (and possibly ethical) bedrocks and reformist tendencies. Also, humour is actually built on intersubjectivity, sociality, and reform.

In this essay, I want to address the possibility of ethical significance within the discourse of comedy and humour mainly in a literary/critical agendum. Accordingly, I suggest that in the critical discussions of comedy, humour and reform, we can look for an ethical aspect, highlight it and restudy its significance with a closer attention. When it comes to ethics, any informed reader is reminded of Emmanuel Levinas (1906-1995), the famous twentieth-century philosopher of ethics. If, following him, we think of the totality of social systems, ideologies and power-relations as an embodiment of closedness (un-openness) to others - especially with regard to inescapable instrumentalisations, totalisations and universalisations that we witness in political systems, laws and socio-ideological intricacies as they run a society ${ }^{1}-$ then I think effective comedy and humour can yield an opportunity to see this closedness eliminated in favour of an openness or hospitality. I aim to study this openness with a closer attention to suggest that it is, in fact, this openness that engenders the possibility of effective comedy and humour - that is to say this openness comes prior to humour and comedy and makes these moments possible and more effective. Without this ethical openness, I suppose, humour or comedy is hardly possible and does not take place effectively.

I call effective any comic humour that carries out its (social or (inter)personal) objective properly and meaningfully, and afflicts its target ethically as it also possibly provokes (sometimes bitter) pleasure and laughter. The precondition of such humour, I submit, is an ethical hospitality and openness; humour takes place only after a relationship is established, and this is where ethics already lies. In comic or humorous situations and occasions of festive laughter - moments such as Mikhail Bakhtin's (1895-1975) carnival which he locates in Rabelais and Shakespeare especially - there is, if they are carried out effectively, an openness among people which is also supposed to be part and parcel of "the ethical" and an ethical encounter: this is what Levinas calls hospitality, "welcoming the Other" (1969: 27) or "a home open to the Other" (1969: 172). I suggest that a Levinasian hospitality - on which I will shed more light - is behind almost any effective comedy/humour, and this ethicality can be the engine of "the comic."

Numerous philosophers have discussed comedy, humour and laughter - from Plato and Aristotle to Immanuel Kant to Bergson to Bakhtin to Simon Critchley - but I think Bakhtin and Levinas have a few interesting points to make in a jointed discussion of ethics and comedy/humour. Contra my thesis in this essay, Critchley (2002) might suggest that people, joke-tellers and humourists must all take part in a social, cultural, intellectual and lingual totality to first recognise funny matters and then begin joking. This is a sound judgement and humour does really seem to be a totality of language and culture, but I think this is exactly where we should start to "reduce" it further and discover what actually comes before this totality. I propose that this comic totality is preceded by a pre-original ethical sensibility to first receive one another

${ }^{1}$ Levinas comments on the "universal law" and the possibility of "tyranny" (1969: 253), and goes on to suggest that "politics left to itself bears a tyranny within itself; it deforms the I and the other who have given rise to it, for it judges them according to universal rules, and thus as in absentia" (300). The uniqueness of each and every person, for instance, is usually ignored by laws in favor of a universality. 
and establish a relationship, and then possibly recognise the jokes and begin joking. If there is no such prior openness and reception, no effective totality such as comedy/humour can take place. And ineffective comedy/humour can hardly be read as comic or humorous at all.

In this essay, then, I try to show how effective comedy/humour is entailed with, and contains, an ethical significance, a moment when "the ontological" or worldly is interrupted by "the ethical" (what I call comedic interruption) to open our home to others. ${ }^{2}$ Levinasian ethics can specify this home and open its door, while comedy, humour and Bakhtinian ideas such as carnival and dialogic relation can let the Other in. Firstly, I will try to "reduce" the original (ontological) socio-political totalities to the comic moment and then to a pre-original (non)moment of ethical sensibility and openness. This is what happens in many comedies and humorous works of literature. ${ }^{3}$ This reduction will expose us to "hospitality" that I deem necessary for effective comedy/humour. The following reverse trajectory shows my main attempt in this essay (from right to left):

(pre-original ethical sensibility) $\leftarrow$ comedy, humour, carnival $\leftarrow$ socio-political totalities ${ }^{4}$

Secondly, I will try to argue that even if comedy/humour is another form of totality - it does require "recognition," among other things, to be meaningful and effective - this totality is actually built on an ethical bedrock, especially if it is to be effective. In fact, whenever afflicting humour takes place between at least two human agents, ${ }^{5}$ we should be alarmed and look for an ethical sensibility between them, perhaps an ethical sublimity which is lurking behind and prior to the humour, actually making it possible. The significance of language and dialogic experience - coupled with ethics, "the essence of language" turns out to be "friendship and hospitality" (Levinas 1969: 305) - will also be discussed from both Levinasian and Bakhtinian points of view. To contextualise my arguments, I will finally read two classic examples of moments of effective humour and comic repartees which are actually preceded by ethical hospitality.

\section{Comedy, humour and the ethical reduction}

As Nealon (1997: 133) has argued, "[b]oth Bakhtin and Levinas insist that ethics exist in an open and ongoing obligation to respond to the other, rather than a static march toward some philosophical end or conclusion." These two thinkers are also both referred to as the

\footnotetext{
${ }^{2}$ It seems that the whole of Levinas's philosophy revolves around this ethical reduction of "the ontological," to have a glance at the enigmatic and elusive rays of the pre-original Good.

${ }^{3}$ Although I will study Shakespeare at the end of this essay as a classic figure, this idea can be addressed in works of comedy, such as those of Ben Jonson and his followers, or even the $19^{\text {th }}$ and $20^{\text {th }}$ century comedies, such as Henrik Ibsen's, George Bernard Shaw's or Oscar Wilde's works. Two specific examples which I admire ethically, are Shaw's Pygmalion (ca. 1913) and James M. Barrie's The Admirable Crichton (1902); both of these works, especially the latter, contain numerous carnivalesque (and thereby ethical) elements. This theme can also be addressed in works which are not mainly comic or humorous, but contain (passing) comic moments. In fact, I will comment on two tragedies by Shakespeare which contain comic elements and moments, and these are highly effective when we look at them from an ethical perspective. Also, I have extensively discussed the ethical role of the Fool's comedy in Lear elsewhere (Bidgoli 2020).

${ }^{4} \mathrm{I}$ am perfectly aware that this is a somehow reductive explanation because Levinas talks about this "preoriginality" as a past that never comes to present ("an immemorial past"), yet this is a risk to be taken if we are to rationalise the way effective comedy/humour has already gained an ethical significance prior to its initiation. I have put the pre-original section within parentheses to show its uncanniness.

${ }^{5}$ By "afflicting," I mean that a(n ethical) purpose is carried out either successfully or unsuccessfully by the subject who jokes; the purpose can be personal or social, cultural or political, in order to contribute to a general (ethical) betterment.
} 
predecessors of "the ethical turn" in the humanities (Steinby \& Klapuri 2013: xx). Even so, it is also argued that Bakhtin's ethics and his notion of "the other" is somehow different from Levinas's philosophy of the Other (Bakhtin 1990, Nealon 1997). While the Other for Levinas takes an abstract transcendence, for Bakhtin s/he is more like a "co-subject: one to whom we listen when he speaks, whom we speak to, whose words we include in our own speech" (Steinby \& Klapuri 2013: xi). This reminds us that for Bakhtin dialogic experience is prior to other experiences, while for Levinas the (non)experience of the non-phenomenon of "the face" Levinas calls the face "a fundamental event" (1988: 168) ${ }^{6}$ - comes even prior to language and dialogue. Thus, the responsible subject's hospitality equals his/her pre-original and pre-lingual exposure to the other person; the subject is already chosen, before being able to choose.

Bakhtin and Levinas part ways on certain other occasions as well. Bakhtin's (1990: 3841) subject, ${ }^{7}$ for instance, is more fluid and self-redeeming, for, as Nealon (1997: 139) suggests, s/he constantly returns to his/her "self" after various encounters with the other person. While Bakhtin's subject continually undergoes Odyssean adventures, Levinas's Abrahamic subject leaves his/her home (metaphorically "the Self") never to return. For Bakhtin, the subject gives and receives (reciprocity), but for Levinas, the subject gives ("to give to the other even the bread out of one's own mouth and the coat from one's shoulders;" see Levinas 1991: 55) without any thought of return (non-reciprocity). These were but a few points to remind the reader that Bakhtin and Levinas are not two identical thinkers. But they both take "ethics" seriously into account, a fact which sufficiently supports my purposes in this essay. Levinas can provide the abstract bedrock of ethical awareness and responsibility, and Bakhtin can practically put that into (comedic) dialogue and "answerability" through his theories such as "carnival." As Holquist (2002: 14) ${ }^{8}$ argues, "[d]ialogue is an obvious master key to the assumptions that guided Bakhtin's work throughout his whole career." The term dialogism - an -ism added to the Bakhtin scholarship by Holquist himself - refers to this (ethical) precedence of dialogue in Bakhtin's works: dialogism "sees social and ethical values as the means by which the fundamental I/other split articulates itself in specific situations" (Holquist 2002: 31-32; my emphasis). Therefore, even if the two thinkers at times approach ethics differently, yet for both of them, ethical sensibility, the other person and dialogue are of paramount significance. "Both Bakhtin and Levinas set out on a quest to recover ethics," says Daphna Erdinast-Vulcan (2008: 44), "in the absence or against the silence of God; both can no longer find consolation in the metaphysics of presence and totality, or resort to the legacy of the absolute; both have been disinherited in more than one sense."

There is another problem that might haunt us here. It can definitely seem odd to any reader familiar with Levinas to study an essay on comedy and humour inspired by his philosophy. Levinas seldom talked about comedy or humour, and his works revolved around serious matters, e.g. Nazism, war, concentration camps, Holocaust, etc. But are we not possibly mistaking comedy or taking it lightly here? Comedy, if it is carried out purposefully (a preoriginal ethical (non)purpose) and effectively, is not just emptily fun or ridiculous. Au contraire, it can be a means to communicate more serious issues in alternative tones and manners; it turns out to be sometimes as effective as (or even more effective than) tragedy. Indeed, a meaningful and rigorous comedy/humour often contains various ironies, plus social and ethical undertones.

\footnotetext{
${ }^{6}$ This suggests that the face is not merely the phenomenon or appearance of something, but a command, the Biblical "Thou Shalt Not Kill." When we encounter the face, we cannot thematise it as an object of knowledge, but first and foremost, we must "respond."

${ }^{7}$ For Bakhtin, subjectivity can be defined as a tripartite of I-for-myself, I-for-other, other-for-me.

${ }^{8}$ It is correctly noted by Nealon that one Bakhtin scholar who focused on the ethical aspects of Bakhtin's work is Michael Holquist (Nealon 1997: 146).
} 
Along these lines, it is justifiable to invoke a figure such as Levinas - despite the fact that he spoke of comedy or humour very little - especially when we are dealing with ethics. ${ }^{9}$

Levinas, in his book Entre-nous: On Thinking-of-the-Other, interestingly mentions that "comedy begins with our simplest gestures" (1998: 3; my emphasis). This passing remark seems very significant. We need to ask: what are these simplest gestures and what, if anything, do they signify? I suggest that an invocation of Bakhtin's ethics (1990) and moments and effects of "the carnivalesque" (1984a, 1984b) can be beneficial here, because I think not only these two thoughts can, in a certain sense, be closely related to each other, but Bakhtin can help us trace and discover those simple gestures. According to Bakhtin (1984b: 8-10), carnival offers that moment of "simplicity" when socio-ideological complexities vanish, and a possibility for (social/ethical) criticism and an opportunity of pure togetherness interrupt a hierarchal history of boundaries. As Levinas (1991: 43) similarly mentions - although with a more vigorous ethical import - this can be the possibility for "a responsibility for another... an interruption of essence... a disinterestedness imposed with a good violence." This elimination of hierarchies and achievement of disinterestedness, harmony and accommodation - though temporary and ephemeral - can specify an ethical moment of supreme significance (but not thoroughly discussed by Bakhtin 1990). It is through this ethical sensibility that a master and his slave or a king and his jester become two humans (and not predefined socio-political agents) and feel an "openness" to one another - are these moments not similar to the hospitable moments of "welcoming the Other?" In an effective comedy or a humorous situation, the master or the king receives and hears the comic gestures and words of his slave or jester as they are - as comedic jokes to raise laughter. On the one hand, Critchley (2002: 4) is right to point out that there must be a social congruity between comedians or humourists and people to "recognise" the funny matters and jokes. On the other hand, Liz Sills (2017: 9), in an essay on the phenomenology of jokes and laughter, also points out that jokes are funny insofar as they are received precisely as jokes. Prior to comic/humorous moments, I thus suggest, socio-political, arbitrary taboos and other predetermined ranks, principles, totalities and demarcations must fade away; this is one of the ways in which authentic, ethical "proximity"10 and "hospitality" are located, and the way an effective comedy or humour is carried out. This is when the slave calls into question his/her master and the master receives this offence to his/her home as a joke. Can it somehow (though not entirely) be also the birth of ethical language as Levinas (1969: 171) has in mind, which is "[t]he calling in question of the I, coextensive with the manifestation of the Other in the face?"

Anyway, I contend this "receiving" and the sense of "openness" or "hospitality" are related ideas and they have a salient ethical significance: prior to fundamentally effective moments of comedy/humour, human relations are freed from socio-political totalities and strictures. But before comedy and humour take place effectively, purposefully and thus ethically, "hospitality" must set the scene. This is, indeed, the precondition of an effective comedy/humour. In such situations, a "human" encounters another "human" - it is not a "master-slave" relationship anymore - and one feels and acknowledges the other and possibly responds to his/her words and/or ailments. ${ }^{11}$ So, language, at least in one sense - hospitality, proximity, dialogue and response rather than understanding and violence - can originate from

\footnotetext{
${ }^{9}$ In spite of all such accounts of seriousness that I referred to here, I would like to have the reader take a look at two somehow comic anecdotes about Levinas's real life, one presented by Derrida (1999: 12), the other by Critchley (2002: 107). Both of these anecdotes, along with some of the existing recorded interviews, suggest that Levinas was seemingly a smiling and mellow person, and probably would not scorn or underestimate humor and its deep effects.

${ }^{10}$ Levinas does not believe in achieving or grasping or understanding the Other; there can only be "proximity" to him/her and this does not refer to geometry but acknowledgement.

${ }^{11}$ I deliberately refuse to say they "understand" one another, because "understanding carries out an act of violence and negation" (Levinas 1998: 9).
} 
such moments of ethical height and comedic depth. This reduction of originality to the preoriginality of ethical sensibility is, I should repeat, the precondition of the effective impact of comedy and humour. Although comedy can be another totality in which jokes are recognised as jokes, I think this totality is almost impossible without an ethical hospitality.

In carnivals and festivities, people are thus usually first involved in hospitality and proximity; jokes, laughter and dialogue come secondary to this ethical experience if they are to be meaningful and effective. If such comic moments are also versions of totality as Critchley defines them, they are actually preceded by an ethical reduction, when ontological (social, political, ideological) boundaries between the Self and the Other fade away (though there be secondarily a totality called comedy or humour) and they open themselves to one another and receive each other. This resembles the moment I referred to above, when the original (worldly or ontological) "said"12 (le dit) is reduced to the pre-original (ethical) "saying"13 (le dire) (Levinas 1991: 43-45). Loosely speaking, in this reduction a trace of "the ethical" can manifest itself in "the ontological." This is when ethics is incarnated as ontology and "the word" through what I here call a comedic interruption. As Levinas (1998: 63) suggests, "in this rupture, and in this awakening, and in this expiation, and in this exaltation, the divine comedy of a transcendence beyond ontological positions unfolds."

To support Levinas's rather pre-linguistic ethical theory and his emphasis on the face, let me refer to an interesting primal humorous act known as "pick-a-boo." In this comic act, which is better appreciated by a pre-lingual infant, a non-linguistic joke plays on object permanence and centres on the face of the Other. When the comic act is played out, infants find it hilarious that the face disappears and then suddenly reappears. Even when we become linguistic in our humour (indeed, the overwhelming focus of most philosophies of humour is precisely linguistic), the origin of humour is still there in the pre-linguistic recognition of the face of the Other.

The significance of language and dialogue should also be clarified here, for they are the only means to effectively relate a "Self" to an "Other." Although language is linked to (often reductive) manifestations and representations, its (pre)original function is to act as a purposeful bridge of "proximity" between me and the other person, as an ethical sensibility and responsibility. For Levinas, "the signifyingness of signification" of language (1991: 5) is first and foremost ethical, "the presence of the Other ... is heard as language" (1969: 297) and "the essence of language is [goodness,] friendship and hospitality" (1969: 305). According to Levinas, language is both a matter of "relationship" with (1969:251) and "response" to the other person (1969: 219). As he mentions in an interview, "the beginning of language is in the face. In a certain way, in its silence, it calls you. Your reaction to the face is a response. Not just a response, but a responsibility" (1988: 169). Levinas (1988: 169-170) goes on to suggest that "[1] anguage does not begin with the signs that one gives, with words. Language is above all the fact of being addressed... which means the saying much more than the said." But though we are pre-originally called by the Other (and the Good), we yet need to respond, that is to say we are also ineluctably bound to language and "the said."

Also, for Bakhtin, acting and interacting require language (it is language that is the soul of interactions and gives rise and meaning to them), and the whole history is based on, and defined by dialogues. If for Levinas "the ethical" comes prior to language (Levinas 1991), for Bakhtin, language and dialogue gain priority (Bakhtin 1990, Nealon 1997). As it is discussed by Nealon (1997: 132-133) and in another detailed discussion by Murray (2000: 134), however,

12 "The said," according to Levinas, is the thematic, signitive language of ontology which tries to bind any entity in thematic frameworks and totalities.

13 "The saying" refers to the ethical sensibility that is pre-cognitive, pre-original, precisely prior to and beyond ontology. 
Levinas's ethical idea of "responsibility" can be linked to Bakhtin's dialogic idea of "answerability." For Levinas, responsibility is an ethical sensibility and for Bakhtin, answerability is a matter of dialogue prior to other specifications, and they can complement one another. Similar to Levinas, moreover, Bakhtin (1984a: 79) suggests that "monologic artistic world does not recognise someone else's thought, someone else's idea, as an object of representation" (my emphasis). It is carnival, according to Bakhtin, that gives rise to an authentic dialogism and provides "a new mode of interrelationship between individuals, counterposed to the all-powerful socio-hierarchal relationships of noncarnival life. The behaviour, gesture, and discourse of a person are freed from the authority of all hierarchal positions" (Bakhtin 1984a: 123; emphasis in the original).

Carnival is also defined as "the second world and the second life outside officialdom... people's second life, organised on the basis of laughter... a festive life" (Bakhtin 1984b: 6-8). The word "officialdom" refers to the ruling philosophy of an "established order... hierarchal rank, privileges, norms, and prohibitions," totalities of various essences (Bakhtin 1984b: 10), which is itself the reason "why the tone of the official... was monolithically serious and why the element of laughter is alien to it" (Bakhtin 1984b: 9). Carnival, however, is "the temporary suspension of hierarchal rank," free of "established order," "the peculiar logic of the "inside out,' of the 'turnabout,' of a continual shifting from top to bottom, from front to rear, of numerous parodies and travesties, humiliations, profanations, comic crowning and uncrownings" (Bakhtin 1984b: 11; my emphasis). Carnival and laughter, as Bakhtin defines them, provide a moment of "bracketing" of all hierarchies and totalities, implying a possible ethical encounter between individuals of different walks of life, a possibility for hospitality and openness. In any case, I suggest that Levinas's ethical notion of hospitality is prior to Bakhtin's carnival and Bakhtin implies this as well; if there is no hospitality, there will be no carnival. The opportunity to get out of "officialdom" provides an ontological negation (and an ethical reduction), to enter into a disinterested dialogue with the other person, as a Self relates to an Other regardless of all ranks and socio-political principles.

Laughter is a biological experience which comes after humour and happens when the humorous effect is heightened. It can also emit from both pleasure and bitterness or sadness. In an important essay entitled "Epic and Novel," laughter is defined by Bakhtin specifically as "the remarkable power of making an object come up close... turn it upside down, inside out" (1981: 23). The carnivalesque effect also acts on the "basis of laughter" (1984b: 7). It is "laughter [that] degrades and materialises" (20). In his famous work on Dostoevsky, Bakhtin (1984a: 127) argues that "carnivalistic laughter... is directed toward something higher - toward a shift of authorities and truths, a shift of world orders." For Bakhtin (1984b: 7), this negation through laughter "frees" people from any universality or "dogmatism;" it simplifies the sentiments so that our simplest gestures can give rise to comedy. And it implies an openness toward the Other which thereby gives rise to this basic negation (as the precondition of laughter), bringing our experiences closer to an ethical standard, even to "the beyond of experience" (Levinas 1991: 148).

By and large, as I have discussed up to this point, it seems that carnival produces the socio-ideological negation (reduction) necessary for laughter, and laughter thereby produces the negation (reduction) necessary for an ethical encounter between self and other. As I argued however, if we take a closer look, it turns out that this trajectory actually begins from what Levinas calls "simplest gestures" and finds its context in the Bakhtinian carnival, a situation in which people take part and "live," an idea that "embraces all the people" (Bakhtin 1984b: 7). If there was no "simple" and ethical openness, a relationship could even hardly be established, let alone humour and laughter. I cannot poke fun at anyone I see on the street for instance, and if I 
do, not only people will not accept that and laugh - thus establishing the (comic) relationship they may find me odd or even rude!

$$
\begin{gathered}
\text { (pre-original ethical sensibility) } \begin{array}{c}
\text { comedy, humour and carnival } \\
\text { totalities }
\end{array} \\
\begin{array}{r}
\downarrow \\
\text { (hospitality) }
\end{array} \rightarrow \text { comedy, humour and carnival }
\end{gathered}
$$

So, before humour can take place, there should be an openness to establish a relationship with the Other(s), a relationship in which we serve, rehabilitate and reform. I reduced comedy and humour, during my discussions, to a zero-point of ethical transcendence and hospitality - where the "simplest gestures" can be located - and suggested that even if comedy needs a totality of recognition, this totality is hardly possible without an ethical openness. A pre-original trace of simplicity and hospitality is what can thus lead to effective comedy and humour. Let me repeat that this resembles Levinas's idea of the reduction of the ontological (political systems, socioideological intricacies, etc.) "to the hither side of the said" (Levinas 1991: 45). It can show traces of "the saying" in the ethical openness to the alterity and destitution of the Other. Levinasian commentators and critics have often wondered about such enigmatic moments of insinuation of "the saying" into "the said," and have provided a few answers to this recurring question. ${ }^{14}$ What I suggest in this essay adds another possible answer to it: I think comedy, since it is founded on hospitality (remember Sills's 2017 argument), can also include "the saying" and "the ethical." Thus, I propose a pre-original ethical moment of simplicity, disinterestedness and openness gives rise to effective comedy, humour and laughter, hearing "the echo of the otherwise" in our hospitable dialogue with the other person (Levinas 1991: 44). It is, in fact, this prior ethical sensibility of the subject that sets his/her humour or comedy in motion. And as Critchley (2000: 26) makes my argument clear with a final shot, that is, "ethical subjectivity is comic rather than tragic." 15

\section{From comedy and carnival to dialogue to hospitality}

In this final section, I embark upon the two ideas I discussed in the main body of this essay "ethical reduction" and "comedic interruption" - to show that many effective humorous/comic situations are actually built upon a prior ethical openness, an openness without which that comedy would have been almost impossible. One might criticise that in this seemingly mutual relationship that I have defined between ethics and comedy, it is also ethics that is dependent on comedy. I would reply that (a) "ethical sensibility" had been already there before humour could take place (ethics gives birth to comedy), and (b) an effective comedy is almost impossible without an ethical openness, but "the ethical" can well show up in an utmost tragic situation where comedy can hardly be felt. ${ }^{16}$

${ }^{14}$ As Amit Pinchevski (2005: 223) sums up in his essay, "Rupturing, erring and inflecting are perhaps the more compelling ways chosen by scholars to describe the involvement of the Saying in the Said" (my emphasis).

${ }^{15}$ In fact, Critchley (2000: 26) very passingly refers to this significance of comedy and the scope and aims of his essay do not allow him to expand this idea.

${ }^{16}$ I encourage the reader to think of the final disastrous moments of King Lear as a very salient example. While these final moments are replete with ethical implications, as many critics have argued, comedy/humour is hardly felt in these moments (and the Fool, as the comic force of the play, had already disappeared when the fourth act opened). 
Bakhtin describes the Renaissance conception of laughter (as opposed to later conceptions) in the introduction to his Rabelais and His World (1984b):

Laughter has a deep philosophical meaning, it is one of the essential forms of the truth concerning the world as a whole, concerning history and man; it is a peculiar point of view relative to the world; the world is seen anew, no less (and perhaps more) profoundly than when seen from the serious standpoint. Therefore, laughter is just as admissible in great literature, posing universal problems, as seriousness. Certain essential aspects of the world are accessible only to laughter (Bakhtin 1984b: 66).

Bakhtin has already posited the grand theme of comedy and laughter in "great literature." Carnival is the locus of laughter and in it, "the walls" or boundaries of the "official" and the "nonofficial... crumble" (Bakhtin 1984b: 72). This is done, for instance, through the "adoption of the vernacular by literature and by certain ideological spheres" (Bakhtin 1984b: 72) which can be, in itself, a counterhegemonic act. In this regard, comedy never remains emptily laughterprovoking. For Bakhtin, comedy and laughter can be our only means to arrive at certain truths.

It can also address ethical issues which are inescapably (pre-originally) involved in such dialogism. Let me invoke here a delicate example offered by Lane in his chapter on Bakhtin. Lane (2006: 12) suggests that "irony" can best exemplify the "relationship, or tension, with another voice." He goes on to argue that in irony, "not only does a statement have two competing meanings, but this double-voiced structure is deliberately aimed at a listener or receiver" (Lane 2006: 12). This, on the surface, refers to the significance of an ironic dialogue both internally (internal multiplicity of voices in a series of utterances) and externally (an address to the other person). But herein already lies the voice of the Other, which is both a "heard" and "an unheardof proposition, an insinuation, immediately reduced to nothing" (Levinas 1987a: 70). This is where the voice of the Other vibrates ("the echo of the otherwise"), and we can sense it, in turn, through the "ethical reduction" that I discussed. It is now clearer how irony (as one important aspect of comedy) is preceded by "the ethical."

Such ironies are also received precisely as ironies, and they can find their context in carnivals. Examples of these carnivals can, as Bakhtin (1984b: 306) showed, best be witnessed in renaissance literary works. According to him, Shakespeare is a more satirical writer than most great literary figures, namely Rabelais and Cervantes. For Bakhtin (1984b: 275), Shakespeare's dramatic works are full of "carnivalesque aspects: images of the material bodily lower stratum, of ambivalent obscenities, and of popular banquet scenes," where the elements of comedy, irony and laughter present; here is where comedy meets "the ethical" as well. As I have invoked Shakespeare - and he was a significantly inspiring thinker for Levinas as well ${ }^{17}$ - let me point to two of his masterpieces, King Lear and Hamlet, ${ }^{18}$ to study a few effective ethical-comicaldialogical moments.

In Hamlet, there are certain moments when the prince's "antic disposition" marks a reduction or simplification of social hierarchies between himself, courtiers, his mother, the King, and other ordinary people (e.g. the Gravediggers) and gives rise to dialogic ironies and comicalities. And these same moments are already reminiscent of (a) Hamlet's alterity as "the Other" as well as (b) the possibility of openness and face-to-face encounters. I specifically refer

\footnotetext{
${ }^{17}$ Levinas's (1987b: 72) exciting claim "it sometimes seems to me that the whole of philosophy is only a meditation of Shakespeare" is just one example of his enormous interest in, and reverence for, Shakespeare. There is also a growing body of scholarly works devoted to this specific and uncanny conjunction (see, for instance, Gold et al. 2018).

${ }^{18}$ In the remaining paragraphs of this essay, I briefly discuss Hamlet and Lear. I have used John Dover Wilson's editions of Shakespeare's plays (Shakespeare 2009a and 2009b).
} 
to a number of Hamlet's comic dialogues with Polonius. As Claudius and Polonius try to "pluck out" the heart of Hamlet's secret, Hamlet's (feigned) otherness and poignantly ironic language confuse them. Hamlet expresses his inscrutable alterity as "you cannot, sir, take from me any thing that I will more willingly part withal" (Shakespeare 2009a: 2.2.218-219) and he goes on to repeat "except my life, except my life, except my life" (219-220); Levinas's (1969: 198) words here come to mind: "I can wish to kill only an existent absolutely independent, which exceeds my powers infinitely, and therefore does not oppose them but paralyses the very power of power. The Other is the sole being I can wish to kill." Even though Hamlet's humorously browbeating discussions with Polonius are highly effective moves to take Polonius (and his uncle) out of their reductive and vain trial to thematise his mystery, Polonius is so dipped in this superficial adventure of reducing Hamlet's mystery to a madness for Ophelia (or anything else) that he does not recognise Hamlet's sharply purposeful words (or if he does, he blindly ignores them and moves on his tragic path, and finally loses his life).

But there are other comic moments which embody "openness" as well. In act three, scene two, Hamlet, who has already put aside matters of formality and courtesy typical of a sociallyand politically-defined prince, asks Polonius rather playfully, "do you see yonder cloud that's almost in shape of a camel?... methinks it is like a weasel...or like a whale?" (Shakespeare 2009a: 3.2.378-379). How should Polonius (and we) make sense of Hamlet's words? They are certainly ironic and multidimensional. In a broad sense, I think, Hamlet is here ironically referring to his own words that he mentioned earlier rather seriously: "there is nothing either good or bad, but thinking makes it so" (2.2.252-253; my emphasis). Through his comic dialogue with Polonius, Hamlet is pointing to the ethically violent accounts of empirical mind-readings and theoretical knowledge which reductively tend to treat the Other like an object or phenomenon. Along the same lines, Hamlet also ironically warns his friends, Rosencrantz and Guildenstern, that "do you think I am easier to be played on than a pipe? Call me what instrument you will, though you can fret me, you cannot play upon me" (3.2.372-374). Hamlet - or we can perhaps say Shakespeare, because Bakhtin (in Lane 2006: 12) would say that Shakespeare's own voice can also be heard in these dialogues - does not seemingly believe in such empiricism and tries to protest against it. The "antic disposition" signifies at least two ideas: the ethical significance of alterity and the power of comedy and humour. "Ransacking Hamlet" as Bloom (2003: 133) reminds us, "is a losing process" and this is the ethical significance of Hamlet which is more fully recognisable in comic moments. Had Polonius and others been "open" to Hamlet's otherness and received his humour, they would perhaps have not embarked upon their fated adventure in the first place; in that occasion, they had a better chance of feeling along with him and sympathise with his miserable melancholy, as Horatio does.

King Lear is also comic at times, especially when the Fool speaks and makes fun of Lear. The Fool introduces various grand carnival moments, moments of highly afflicting and effective humour when all hierarchies are ruptured. At certain moments, the King and his jester are seen in dialogue as two humans, not politically- and socially-defined agents. Lear is enraged once or twice, yet he cannot help openly hear the Fool as he effectively points to his kingly follies and jokingly criticises his mind-set. When Lear, for instance, wonders about Goneril's frowning, the Fool playfully mocks Lear:

Thou wast a pretty fellow when thou

Hadst no need to care for her frowning; now

Thou art an $\mathrm{O}$ without a figure. I am better

Than thou art now; I am a fool, thou art

Nothing. (Shakespeare 2009b: 1.4.212-217) 
It is quite exciting that the Fool fears nothing when he speaks in such a bitter/comic language to a king. He is comic, ironic, bitter and (most significantly) ethical, all at the same time. With a similar hindsight, Levinas invokes Shakespeare's fools in one of his earlier books as follows:

The Buffoon, the fool of Shakespearean tragedy, is the one who feels and bespeaks with lucidity the unsubstantiality of the world and the absurdity of its situations - the one who is not the principal character of the tragedy, the one who has nothing to overcome. In a world of kings, and princes, and heroes, the fool is the opening through which this world is swept by drafts of madness. (Levinas 1987b: 59)

The Fool, "who is not the principal character of the tragedy," joins the wrecks of King Lear, sets up an afflicting carnival of comedy and reduces every character to a basically human level. The Fool's humour fears nothing and nobody, and this is what revolutionises his master. Lear, as the play progresses, hospitably (even if unconsciously at first) receives the Fool's comic insults as jokes, and thereby feels more and more along with the Other. This culminates in act three, scene four, where he openly welcomes Poor Tom as the wretched Other (Shakespeare 2009b: 3.4.26110). In one sense, Lear's ethical awakening comes about as a result of the Fool's ethical comicality (Bidgoli 2020).

This brings us to serious and tragic sensations as well. In fact, comedy and humour sometimes go hand in hand with tragedy because, as I mentioned above, they are not only never emptily ludicrous but are actually replete with effective and serious ethical and social critiques. This is fully felt in Shakespeare's Hamlet and King Lear. "In world literature there are certain works in which the two aspects, seriousness and laughter, coexist and reflect each other," argues Bakhtin (1984b: 122), "and are indeed whole aspects, not separate serious and comic images as in the usual modern drama... the most important works in this category are, of course, Shakespeare's tragedies." The two examples that I studied here are among these comic/tragic works. They depict moments of carnivalesque features, when people are involved in disinterested encounters and dialogues, outside "officialdom," and the effectiveness of their relationship hints at a pre-original ethical import. As I clarified, these were comic moments when predefined orders, ranks and political principles were wiped away; we could discuss unique senses of ethics and alterity witnessed in the heights of comedy and humour, irony and laughter.

To wrap up, let me repeat that my proposal and its supporting arguments were mainly literary/critical in nature. I tried to provide literary critics with a possible framework to think about comedy, humour and ethics in literature. More research can be conducted on the way comedy and humour can be appreciated differently, perhaps more effectively and ethically; discussions about the possibility of the ethical significance of comedy and humour can pave the way for more novel inquiries into comedy/humour studies in particular and ethical criticism in general. Finally, it should be noted that broader cultural, social and perhaps philosophical studies of the ethical significance of comedy, humour and laughter are open to be addressed by thinkers interested in this specific field.

\section{References}

Aristotle (1996). Poetics. Heath, M. (trans.), London: Penguin Books.

Bakhtin, M. M. (1981). The Dialogic Imagination: Four Essays. Holquist, M. \& Emerson, C. (eds. \& trans.), Austin: University of Texas Press. 
Bakhtin, M. M. (1984a). 'Problems of Dostoevsky's poetics'. In Emerson, C. (ed. \& trans.), Theory and History of Literature. Minneapolis: University of Minnesota Press.

Bakhtin, M. M. (1984b). Rabelais and His World. Iswolsky, H. (trans.), Bloomington: Indiana University Press.

Bakhtin, M. M. (1990). Art and Answerability: Early Philosophical Essays by M. M. Bakhtin. Holquist, M. \& Liapunov, V. (eds.), Austin: University of Texas Press.

Bergson, H. (1980). Laughter. Baltimore: The Johns Hopkins University Press.

Bidgoli, M. (2020). 'Ethical comicality and the Fool: an essay on King Lear'. Comedy Studies. DOI: $10.1080 / 2040610 X .2020 .1729491$

Bloom, H. (2003). Hamlet: Poem Unlimited. New York: Riverhead Books.

Chattoo, C. B. (2018). 'A funny matter: toward a framework for understanding the function of comedy in social change'. Humor, pp. 1-25.

Clarke, R. F. (1965). The Growth and Nature of Drama. London: Cambridge University Press.

Critchley, S. (2000). 'Demanding approval: on the ethics of Alain Badiou'. Radical Philosophy 100, pp. 16-27.

Critchley, S. (2002). On Humour. London: Routledge.

Derrida, J. (1999). Adieu to Emmanuel Levinas. Brault, P-A. \& Naas, M. (trans.), California: Stanford University Press.

Erdinast-Vulcan, D. (2008). 'Between the face and the voice: Bakhtin meets Levinas'. Continental Philosophy Review 41, pp. 43-58.

Gold, M., Goodhart S. \& Lehnhof, K. (2018). Of Levinas and Shakespeare: "To See Another Thus". Indiana: Purdue University Press.

Holquist, M. (2002). Dialogism: Bakhtin and His World (second edition). London: Routledge.

Lane, R. J. (2006). Fifty Key Literary Theorists. Oxon \& NY: Routledge.

Levinas, E. (1969). Totality and Infinity. Lingis, A. (trans), Pittsburgh: Duquesne University Press.

Levinas, E. (1987a). Collected Philosophical Papers. Lingis, A. (trans.), Dordrecht: Martinus Nijhoff Publishers.

Levinas, E. (1987b). Time and the Other (and Additional Essays). Cohen, R. A. (trans.), Pittsburgh: Duquesne University Press.

Levinas, E. (1988). 'The paradox of morality: an interview with Emmanuel Levinas', In Bernasconi, R. \& Wood, D. (eds.), The Provocation of Levinas: Rethinking the Other. Benjamin, A. \& Wright, T. (trans.), London \& NY: Routledge, pp. 168-180.

Levinas, E. (1991). Otherwise than Being or Beyond Essence. Lingis, A. (trans.), Dordrecht: Kluwer Academic Publishers.

Levinas, E. (1998). Entre-Nous: on Thinking-of-the-Other. Smith, M. B. \& Harshav, B. (trans.), New York: Columbia University Press.

Murray, J. W. (2000). 'Bakhtinian answerability and Levinasian responsibility: forging a fuller dialogical communicative ethics'. Southern Communication Journal 65 (2-3), pp. 133-150.

Nealon, J. T. (1997). 'The ethics of dialogue: Bakhtin and Levinas'. College English 59 (2), pp. 129-148.

Pinchevski, A. 2005. 'The ethics of interruption: toward a Levinasian philosophy of communication'. Social Semiotics 15(2), pp. 211-234.

Shakespeare, W. (2009a) [1934]. Hamlet, prince of Denmark. Wilson, J. D. (ed.), Cambridge: Cambridge University Press.

Shakespeare, W. (2009b) [1960]. King Lear. Wilson, J. D. (ed.), Cambridge: Cambridge University Press.

Shaw, C. (2014). Satyric Play: The Evolution of Greek Comedy and Satyr Drama. London: Oxford University Press. 
Sills, L. (2017). 'The phenomenology of the funny: a diagrammatical proposal'. Comedy Studies 8 (1), pp. 2-12.

Steinby, L. \& Klapuri, T. (2013). 'The acting subject of Bakhtin', In Steinby, L. \& Klapuri, T. (eds.), Bakhtin and His Others. London: Anthem Press. 